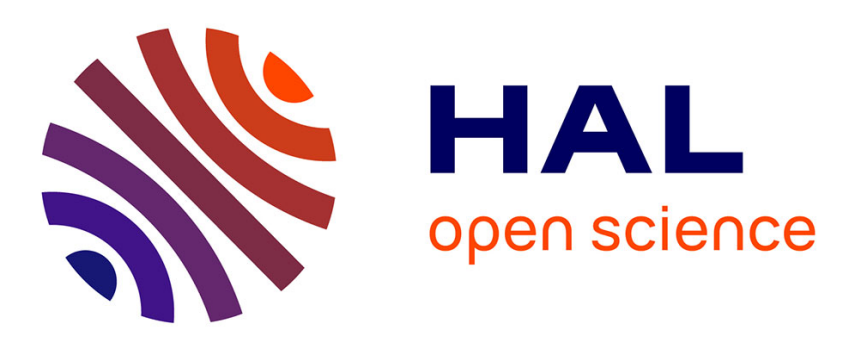

\title{
Dynamics and active processes: the albanian natural laboratory and analogues.
}

Francois Roure, Magdalena Scheck-Wenderoth, Liviu Matenco, Kristaq Muska, Shaqir Nazai

\section{- To cite this version:}

Francois Roure, Magdalena Scheck-Wenderoth, Liviu Matenco, Kristaq Muska, Shaqir Nazai. Dynamics and active processes: the albanian natural laboratory and analogues.. Italian of Geosciences, 2013, 132 (2), pp.169-174. 10.3301/IJG.2013.03 . hal-01071668

\section{HAL Id: hal-01071668 \\ https://hal-ifp.archives-ouvertes.fr/hal-01071668}

Submitted on 6 Oct 2014

HAL is a multi-disciplinary open access archive for the deposit and dissemination of scientific research documents, whether they are published or not. The documents may come from teaching and research institutions in France or abroad, or from public or private research centers.
L'archive ouverte pluridisciplinaire HAL, est destinée au dépôt et à la diffusion de documents scientifiques de niveau recherche, publiés ou non, émanant des établissements d'enseignement et de recherche français ou étrangers, des laboratoires publics ou privés. 


\title{
DYNAMICS and ACTIVE PROCESSES: The ALBANIAN NATURAL LABORATORY and ANALOGUES
}

\author{
François ROURE*,**, Magdalena SCHECK-WENDEROTH***, Liviu MATENCO**, \\ Kristaq MUSKA **** and Shaqir NAZAI**** \\ *IFP-Energies Nouvelles, Rueil-Malmaison, France \\ **Utrecht Univ., the Netherlands \\ ***GFZ, Potsdam, Germany \\ **** Polytechnic Univ, of Tirana, Albania
}

Corresponding author: Francois.Roure@,ifpen.fr

\section{1- Introduction}

This special issue of the Italian Journal of Geosciences provides a selection of 7 papers which have been presented during the sixth workshop of the ILP Task Force on Sedimentary Basins, hosted at the Polytechnic University of Tirana on November 7-12, 2010. More than 100 Earth scientists, professionals and students participated to this workshop, including $70 \%$ of Albanian colleagues, mainly from the Polytechnic University, geological survey, academy and oil industry, and $30 \%$ of participants from universities, research centers and companies from other European countries (Austria, Belgium, France, Germany, Italy, the Netherlands, Romania, Switzerland), as well as North and South America and the Middle-East. Plenary sessions and further discussions during the pre- and post-conference field trips (Figure 1), were dominantly focused on Albania, which, thanks to its extensive petroleum exploration and modern seismological and GPS networks, constitutes the best documented natural laboratory for the study of active onshore compressional systems in Europe.

This conference generated excellent discussions on the 3 main topics developed below.

\section{2- Geodynamic evolution and paleogeography of Albania and adjacent Offshore}

Numerous oral presentations and posters focused on the overall tectono-stratigraphic evolution, crustal architecture of the Albanides and adjacent Adriatic Offshore as well as their relationships with the Dinarides and Italian counterparts, which are well documented by a wide set of seismic profiles and exploration wells from the industry (see for instance Roure et al., 1995; Nieuwland et al., 2001; TRANSMED transect III in Carminati et al., 2004 and Cavazza et al., 2004a \& b; Roure et al., 2004, Schmid et al., 2008; Matenco and Radivojevic, 2012; and references therein).

Regional studies have shown that the Albanian foothills result from the Neogene deformation of the former eastern passive margin of Apulia. Located west and south of the Mirdita ophiolite and the Kruja Zone (Fig. 2), the outer zones of the Albanian thrust belt are subdivided in two very distinct tectonic provinces by the NE-trending Vlora-Elbasan lineament, with up to $10 \mathrm{~km}$ of Oligocene to Plio-Quaternary clastics being still currently preserved in the Peri-Adriatic Depression in the northwest, and Mesozoic carbonates of the Ionian Zone being directly exposed at the surface in the south. As evidenced on seismic profiles, the main décollement level is localised within Triassic evaporites and salt in the south, ramp anticlines accounting for the tectonic uplift of Mesozoic carbonates in the Ionian Zone, whereas it is located within the Cenozoic clastics in the north, where no carbonate reservoirs are exposed at the surface (Fig.3). Accordingly, the Vlora-Elbasan transfer zone, 
which is still seismically very active (Aliaj et al., 2000; Papazachos et al., 2001; Jouanne et al., 2012), is best described as a lateral ramp connecting these two distinct décollement surfaces (Roure et al., 1995).

The tectono-stratigraphic evolution of the outer Albanides can be summarised as follows.

\section{Evolution of the Adriatic passive margin and deposition of carbonate reservoirs:}

Presently situated at the transition between two major orogenic belts, the Hellenides and the Dinarides, the kinematic evolution of the Albanides demonstrates common causalities during the opening and closure of the same major oceanic embayment, i.e. the Neotethys (e.g. Schmid et al., 2008; Robertson et al., 2011). The rifting of the Neotethys that started during Middle Triassic times was associated with the emplacement of significant acid to intermediate volcanism (e.g., Monjoie et al., 2008). It also led to the formation of an extensional system that deposited Upper Triassic to locally Cretaceous deep water dominantly carbonatic but also clastic sediments in subsiding grabens, while Upper Triassic to locally Eocene shallow water carbonates reaching more than $2 \mathrm{~km}$ dominated the basins highs (e.g., Vlahovic et al. 2005; Cadjenovic et al., 2008). The facies furthermore deepens northwards towards the internal units of the Dinarides, Albanides and Hellenides, where deep-water radiolaritic sedimentation was deposited directly over the oceanic crust presently exposed as Jurassic obducted ophiolites or as Triassic blocks in ophiolitic melanges (e.g. Gawlick et al., 2008; 2009; Vishnevskaya e.g., 2009; Saccani et al., 2011). The contractional history started with the late Jurassic-earliest Cretaceous ophiolitic obduction and was followed by Cretaceous-Eocene moments of thin-skinned thrusting and nappe emplacement (e.g. Schmid et al., 2008; Schlagintweit et al., 2008; Meshi et al. 2010; Robertson et al., 2010). Thin-skinned thrusting continued during Neogene times with offsets gradually increasing along the strike of the orogenic belt from the Dinarides to Albanides and Hellenides. At the same time, the thrusting was accompanied by Neogene back-arc collapse that is recorded along the strike of the entire orogenic belt (e.g., Muceku et al., 2008; Jolivet et al, 2010; Schefer et al., 2011; Jouanne et al., 2012; Matenco and Radivojevic, 2012).

In the external Albanides, the Middle Triassic (late Anisian) onset of the opening of the Neotethys created a system of local Late Triassic to Liassic tilted blocks and grabens, thick organic-rich limestones and dolomitic platform carbonates characterising the paleo-horsts, whereas deep-water facies such as Liassic black-shales (Posidonia shale) were deposited in the grabens (Zappaterra, 1994), thus accounting for the two main source rocks intervals of the basin. Post-rift thermal subsidence resulted in the deposition of deepwater cherts during the Middle and Upper Jurassic in the Ionian Basin, whereas prograding Cretaceous carbonate platforms from the Kruja Zone in the east, and from the Sazani Zone in the west, contributed as a distal source for the thick carbonate turbidites deposited in the Ionian Basin during the Late Cretaceous and Paleocene (Vilasi, 2009, Vilasi et al., 2006, 2009). These turbidites, which reworked platform carbonate material (Van Geet et al., 2002), are interbedded within finer grained pelagic carbonates, and constitute the main hydrocarbon reservoirs onshore Albania, but also offshore in the Italian part of the Adriatic Sea.

\section{Foothills development and sedimentary records of the deformation:}

Up to $10 \mathrm{~km}$ of synflexural and synkinematic siliciclastic series have been deposited in the Peri-Adriatic Depression, ranging from near-shore and littoral facies in the east and south, toward deeper water and turbiditic facies in the north and in the west (offshore), providing a 
unique and continuous sedimentary record of the deformation (Frasheri et al., 1996). Sequence stratigraphy and biostratigraphy by means of foraminifer and nannoplancton in pelagic facies are able to provide accurate correlations of very good resolution for the dating of geologic events in this basin:

Tectonic loading applied by the hinterland (Mirdita ophiolite) from the Upper Cretaceous onward and westward thrusting of far travelled basinal units of the Krasta Zone induced the progressive development of a wide flexural basin, which ultimately impacted the outer Albanides lithosphere in Oligocene times.

Growth anticlines started to develop in Late Oligocene-Aquitanian in the Ionian Basin (Nieuwland et al., 2001), accounting for the development of Burdigalian reefal facies and paleo-karst at the crest of the Kremenara anticline, this main episode of shortening being sealed by Langhian-Serravalian clastics (Van Geet et al., 2002).

The second episode of tectonic shortening is best documented near the Vlora-Elbasan transfer zone (Roure et al., 1995; Argnani, this volume) and farther north in the Peri-Adriatic Depression, where Pliocene backthrusts account for major lateral and vertical offsets of a preMessinian erosional surface. Although Neogene deposits are mostly absent from the Ionian Zone itself, it is obvious that this post-Messinian tectonic episode strongly affected also the southern part of the Albanian Foothills.

Apart of thrusting and development of ramp anticlines, these Neogene episodes of deformation have also contributed to remobilise former salt diapirs, i.e. in the Dümre area (Fig. 2; Jardin et al., 2011), where an allochthonous salt unit has been thrusted along a low angle fault over underlying carbonate duplexes and deformed Cenozoic clastics.

Further details and a good illustration of the lateral changes observed in the structural style and its paleogeographic controls along the Albania Cost are provided by Andrea Argnani (2013) in the first paper of this special issue.

Post-nappe refolding of the Mirdita allochthon was already documented by Collaku et al. (1990), who identified a wide tectonic window where the Oligocene flysch and Triassic diapirs of the Outer Albanides crop out again in the core of a wide nappe anticline located within the hinterland domain, east of the Mirdita ophiolite. However, new apatite fission tracks and (U-Th)/He thermo-chronology from the Mirdita allochthon (Muceku, 2006; Muceku et al., 2006) have now provided also evidence for the early unroofing of the hinterland, which indeed predates the thrust emplacement of the allochthon over the Outer Albanides. The western Internal Albanides are characterised by slow cooling and low exhumation rate $(0.1 \mathrm{~km} / \mathrm{my})$ throughout the Late Eocene that are related to isostatic uplift as a consequence of crustal thickening near the frontal thrust.

Apart of providing new challenges for Topo-Europe (Cloetingh and Topo-Europe team, 2007), such paleo-topographic constraints may open new perspectives for the exploration of sub-thrust units located east of the Kruja front as they may have escaped cracking beneath a thinner-than-expected allochthon. Proper risk appraisal would however still require to perform a complete coupled kinematic and thermal modelling across the Inner Albanides, using these new data, in order to reconstruct the complete burial and maturation history of potential source rocks in the underthrust foreland (Lacombe et al., 2009; Roure et al., 2010a \& b).

\section{3- Seismic hazards and present day topography of Albania}


Albania as a whole is still a very active tectonic province, and since a long time, Albanian geophysicists have build a national seismologic network and documented the most active areas (Aliaj et al., 2000; Sulstarova et al., 2003). Paleomagnetic data have also documented a strong decoupling of the Ionian allochthon and its progressive rotation with respect to the stable Adriatic foreland (Speranza et al., 1992, 1995).

Two projects supported by NATO (Science for Peace Programme) have also provided new information on tectonically active features of the Albanian foothills, providing an updated synthesis on the gravimetry (Fig. 4), current seismicity, focal mechanisms, recent deformation and uplift of river terraces as well as GPS measurements (Papazachos et al., 2001; Muco et al., 2002a \& b; Kiratzi and Muço, 2004; Guzman et al., 2011; Jouanne et al., 2012).

Alltogether, the focal mechanisms of Albanian earthquakes and the new GPS data outline three distinct tectonic provinces in Albania, i.e. (1) the relatively stable foreland in the Adriatic Offshore, (2) the still active compressional system of the Outer Albanian Foothills, and (3) a currently extensional domain that extends over the former hinterland units, near the Macedonian and Greek borders, in relation with the opening of the Aegean back-arc system.

Within this overall background, the second chapter of this issue is dedicated to the seismic hazard in Albania. It starts with a summary of the focal mechanisms and slip models of moderate size earthquakes in Albania and adjacent counties by Anastasia Kiratzi (2013), and probabilistic seismic hazard assessment in Albania by Bettim Muco (2013).

This chapter comprises also a detailed discussion of 2009 Albanian earthquakes by Ormeni et al. (2013), as well a discussion on liquefaction probability of non-cohesive soils in Semani area by Daja et al. (2013).

\section{4- Petroleum systems and $\mathrm{HC}$ exploration in the Albanides and adjacent Adriatic Offshore}

Albpetrol and the Albanian Petroleum Institute in Fieri have studied since a long time the petroleum occurrences and petroleum systems of the Outer Albanides, even before the opening of the country to foreign exploration companies (Curi, 1993; Frasheri, 2005, and references therein). However, further objectives in subthrust carbonate units have not yet been tested in Albania, making this country still attractive for the exploration (Bega, 2010).

IFP-EN and the Albanian Petroleum Institute in Fieri initiated extensive collaboration in the 90 's, which resulted in the review of the petroleum potential and the co-organization of a field trip for the AAPG in 1995 (Roure et al., 1995). From 1996 to 2002, collaborative studies dedicated to the prediction of reservoir characteristics, coupling both petrographic work and basin modelling, have been the driving force of the SUBThrust Reservoir APpraisal joint industry project (SUBTRAP Consortium; Roure et al., 2005), with case studies dedicated to sandstone reservoirs in Sub-Andean Basins in Venezuela and Colombia, and to carbonate reservoirs in Pakistan, Mexico, Canada, as well as in Albania. During the Albanian part of the SUBTRAP project and more recent collaborations with the Albanian Petroleum Institute and Geological Survey, as well as with the university of Tirana, Triassic dolomites (Muska, 2002) and Upper Cretaceous carbonate turbidites (Swennen et al., 2000; Van Geet et al., 2002; Vilasi, 2009) have been extensively studied. We have also extended the quantification to kinematic and sedimentary modelling in the Outer Albanides by coupling Thrustpack with Dionisos, as well as to fluid flow, pore fluid pressure and hydrocarbon migration modelling with Ceres (Vilasi, 2009; Vilasi et al., 2006 and 2009; Roure et al., 2010a \& b; and references therein). 
In addition to the oral presentations which documented the results of these already published petroleum modelling studies, the last Chapter of this issue is dedicated to the petroleum systems of Albania, with a special focus on the geochemistry of the various families of Albanian oils by Irakli Prifti and Kristak Muska (2013), and on the overall characteristics of Neogene clastic reservoirs of the Vlora-Elbasan region by V. Silo and others (2013).

\section{5- Conclusions}

The final discussion of the ILP Conference in Tirana focussed on on-going projects and perspectives for further international collaborative and integrated projects aiming at the study of the Albanian natural laboratory.

Because Albania is still tectonically very active, it has a very long historical record of earthquakes, and it is very important to secure here for the long term the instrumentation and recording of such natural hazards with a dense network of seismometers and GPS stations.

Field studies dedicated to the search for surface ruptures in the vicinity of major earthquakes are also likely to provide a better understanding of active faults, whereas the integration of both onshore and offshore high resolution seismic profiles recorded by the industry are expected to provide direct constraints on the average velocity and long term history of faults which have been active since the Plio-Pleistocene.

In the perspective of the Topo-Europe initiative, Albania is likely to become one of the most federative arena for the study of active tectonics and vertical motion, with quite challenging questions to be solved. Among others, one very intriguing question is to know how and where does operate the decoupling between the western compressional domain, which extends from the foothills to the Adriatic and Ionian offshore, and the eastern extensional domain, which develops in the hinterland, from the crest of the Mirdita ophiolite to the Macedonian and Greek borders.

TerMex (Terra Mediterranean Experiment) network is also likely to provide soon new opportunities for dedicated training and collaborative work for earth sciences projects aiming at societally relevant topics such as natural hazards, energy and water resources, paleoenvironment and paleo-climate, multi-national databases and long term monitoring.

ICDP plans for drilling in the Ohrid Lake are also expected to generate a strong network among the international earth sciences teams but also among the biodiversity and paleoclimate scientific communities (Hoffmann et al., 2009; Wagner et al., 2009).

Last but not least, the Geological Society of Albania is now holding the flag of the CarpathoBalkanic association, and will host its next meeting in 2014 in Tirana.

\section{6- Acknowledgements}

ILP express its warmest thanks to Pr.Dr. Jorgaq Kaçani (Rector, PU-Tirana), Pr.Dr. Perparim Hoxha (Dean, Faculty of Geology and Mines, PU-Tirana), Prs. Kristaq Muska and Shaqir Nazaj (PU-Tirana) for hosting this very successful conference in the main building of the Polytechnic university. Françoise Rangin and SGF are also acknowledged for their efficient support, website, money transfers and on-line registrations for the Tirana meeting. Last but not least, we would like also to thank the team of the Italian Journal of Geosciences and anonymous referees who helped in improving the chapters of this special issue. 


\section{7- References}

Aliaj Sh, Sulstarova E, Muco B, Kociu S., 2000. Seismotectonic Map of Albania Scale 1:500.000. Seismological Institute, Tirana, Albania.

Argnani A., 2013. The influence of Mesozoic paleogeography on the variations in structural style along the front of the Albanide thrust-and-fold belt. Italian Journal of Geosciences, 132, this issue, DOI: $10.330 /$ IJG.2012.02.

Bega Z., 2010. Platform carbonate subthrusts as major hydrocarbon plays in NW-AlbaniaMontenegro region. ILP-Task Force on Sedimentary Basins, November 7-12, 2010, Tirana, Abst.

Cadjenovic, D., Kilibarda, Z. and Radulovic, N., 2008. Late Triassic to Late Jurassic evolution of the Adriatic Carbonate Platform and Budva Basin, Southern Montenegro. Sedimentary Geology, 204(1-2), 1-17.

Carminati, E. et al. (16 authors), 2004. TRANSMED Transect III: Massif Central - Provence Gulf of Lion - Provençal Basin - Sardinia - Tyrrhenian Basin - Southern Apennines Apulia - Adriatic Sea - Albanides - Balkans - Moesian Platform, in Cavazza, W., Roure, F., Spakman, Stampfli, G.M. and Ziegler, P.A., eds., The TRANSMED Atlas: The Mediterranean Region from Crust to Mantle: Heidelberg, Springer-Verlag.

Cavazza, W., Roure, F., Spakman, Stampfli, G.M. and Ziegler, P.A., eds., 2004a. The TRANSMED Atlas: The Mediterranean Region form Crust to Mantle: Heidelberg, Springer-Verlag, 141 pp. + CD-ROM.

Cavazza W., Ziegler P. and Roure F., 2004b. The Mediterranean area and the surrounding regions: active processes, remnants of former Tethyan oceans and related thrust belts. In Cavazza W., Roure F., Spakman W., Stampfli G.M. and Ziegler P.A., eds., the Transmed Atlas, Springer-Verlag.

Cloetingh, S.A.P.L., Ziegler, P.A., 31 others and TOPO-EUROPE Working Group, 2007. "TOPO-EUROPE: The geoscience of coupled deep Earth-surface processes". Global and Planetary Change, 58, 1-118. DOI: 10.1016/j.gloplacha.2007.02.008.

Collaku A., Cadet J.-P., Melo V., Bonneau M., 1990. Sur l'allochtonie des Albanaises : mise en évidence de fenêtres à l' arrière de la nappe ophiolitique de la Mirdita (Albanie). C.R. Acad. Sci. Paris, 2, 311, 1251-1258.

Curi F., 1993. Oil generation and accumulation in the Albanides Ionian Basin. In: Generation, Accumulation and Production of Europe's Hydrocarbons III, Spencer A.M. (ed.), Special publication of the European Association of Petroleum Geoscientists, 3, 281-293.

Daja S., Shkodrani N., Lako A. and Ago B., 2013. Real liquefaction probability of noncohesive soils in Semani area, Albania. Italian Journal of Geosciences, 132, this issue, DOI: 10.3301/IJG.2011.32.

Frasheri A., 2005. Geothermal regime and hydrocarbon generation in the Albanides. Petroleum Geoscience, 11, 347-352.

Frasheri A., Nishani P., Bushati S., Hyseni A., 1996. Relationship between tectonic zone of the Albanides, based on results of geophysical studies. In: Ziegler, P.A., Horwath, F. (Eds.), PeriTethys Memoir 2: Structure and Prospects of Alpine Basins and Forelands. Mém. Musée Hist. Nat. Paris, $170,485-511$.

Gawlick, H.-J., Frisch, W., Hoxha, L., Dumitrica, P., Krystyn, L., Lein, R., Missoni, S. and Schlagintweit, F., 2008. Mirdita Zone ophiolites and associated sediments in Albania reveal Neotethys Ocean origin. International Journal of Earth Sciences, 97(4), 865-881.

Gawlick, H.J., Sudar, M., Suzuki, H., Deric, N., Missoni, S., Lein, R. and Jovanovic, D., 2009. Upper Triassic and Middle Jurassic radiolarians from the ophiolitic mélange of the Dinaridic Ophiolite Belt, SW Serbia. N. Jb. Geol. Paläont. Abh., 253(2-3), 293-311.

Guzman O., Mugnier, J-L., Koçi, R., Vassallo, R., Carcaillet, J., Jouanne, F., and Fouache., E. 2011. Active Tectonics of Albania Inferred from Fluvial Terraces Geometries 
Proceedings volume of 2, 2011 - 2nd - INQUA - International Workshop in active tectonics, 66-69.

Hoffmann N., Reicherter K., Fernandez-Steeger T. and Arndt M., 2009. Tectonic evolution of the Ohrid basin (Macedonia/Albania): preliminary results for a future ICDP deep drilling site. Geophysical Research Abs., 11, EGU-2009-7835.

Jardin A., Nikolla L. and Roure F., 2011. Subsalt imaging of the Dumre area, Ionian Basin, Albania. OGST, Revue de l'IFP, http://dx.doi.org/10.2516/ogst/2011100.

Jolivet, L. and Brun, J.-P., 2010. Cenozoic geodynamic evolution of the Aegean. International Journal of Earth Sciences, 99(1), 109-138.

Jouanne F., Mugnier J.L., Koci R., Bushati S., Matev K., Kuka N., Shinko I., Kociu S., and Duni, 2012. GPS constraints on current tectonics of Albania. Tectonophysics, 554, 50 62.

Kiratzi A., 2013. Focal mechanisms and slip models of moderate size earthquakes in Albania and adjacent countries. Italian Journal of Geosciences, 132, this issue, DOV/ 10.3301/1JG.2011.33.

Kiratzi, A. and Muço, B., 2004. Seismotectonics and seismic hazard assessment in Albania. Alba-Seis, NATO Science for Peace Programme, final report.

Lacombe O., Malandain J., Vilasi N., Amrouch K. and Roure F., 2009. From paleostresses to paleobutrial in fold-thrust belts: preliminary results from calcite twin analysis in the outer Albanides. Marrakech Proceedings, Tectonophysics, 475, doi: $10.1016 /$ j.tecto.2008.10.023 .

Matenco L. and Radivojevic D., 2012. On the formation and evolution of the Pannonian Basin: Constraints derived from the structure of the junction area between the Carpathians and Dinarides. Tectonics 31, TC6007, doi: 10.1029/2012tc003206

Meshi, A., Boudier, F., Nicolas, A. and Milushi, I., 2010. Structure and tectonics of lower crustal and upper mantle rocks in the Jurassic Mirdita ophiolites, Albania. International Geology Review, 52(2-3), 117-141.

Monjoie, P., Lapierre, H., Tashko, A., Mascle, G.H., Dechamp, A., Muceku, B. and Brunet, P., 2008. Nature and origin of the Triassic volcanism in Albania and Othrys: a key to understanding the Neotethys opening? Bulletin Soc. Géol. France, 179(4), 411-425.

Muceku, B., Beek, P.v.d., Bernet, M., Reiners, P., Mascle, G. and Tashko, A., 2008. Thermochronological evidence for Mio-Pliocene late orogenic extension in the northeastern Albanides (Albania). Terra Nova, 20(3), 180-187.

Muceku, B., Mascle, G. H. \& Tashko, A. 2007. First results of fission-track thermochronology in the Albanides. Geological Society, London, Special Publications, 260, 539-556.

Muço B., 2013. Probabilistic seismic hazard assessment in Albania. Italian Journal of Geosciences, 132, this issue.

Muço, B., Kiratzi, A., Aliaj, Sh., Sulstarova, E., Kociu, S., Peçi, V., 2002a. Probabilistic approach used in Seismic Hazard of Albania, Book of Abstracts, Univ, of Genoa, Italy, 28-th Gen. Ass. of ESC, September 1-6.

Muço B., Vaccari F., Panza G., Kuka N., 2002b. Seismic zonation in Albania using a deterministic approach, Tectonophysics, 344, 277-288.

Muska K., 2002. Thermicité, transferts et diagenèse des réservoirs dans les unités externes des Albanides (Bassin Ionien). PhD Thesis, UPMC Paris VI, IFP Report 56850, 205 pp

Nieuwland D.A., Oudmayer B.C., and Valbona U., 2001. The tectonic development of Albania: explanation and prediction of stuctural styles. Marine and Petroleum Geology, 18, 161-177.

Ormeni R., Fundo A., Daja S. and Doda V., 2013. The strongest earthquakes occurred in Albania during 2009 and their seismogenic zones. Italian Journal of Geosciences, 132, this issue. 
Papazachos, B.C, A. S. Savvaidis, C.B. Papazachos, Ch. A. Papaioannou, A.A. Kiratzi, B. Muco, S. Kociu and S. Sulstarova, 2001. Atlas of Isoseismal Maps for Shallow Earthquakes in Albania and surrounding Area (1851-1990). Publ. Geophys. Lab., Univ. Thesaaloniki, 10, $74 \mathrm{pp}$.

Prifti I. and Muska K., 2013. Hydrocarbon occurrences and petroleum geochemistry of Albanian oils. Italian Journal of Geosciences, 132, this issue.

Robertson, A., Ionescu, C., Hoeck, V., Koller, F., Onuzi, K., Bucur, I. and Ghega, D., 2010. Emplacement of the Jurassic Mirdita ophiolites (southern Albania): evidence from associated clastic and carbonate sediments. International Journal of Earth Sciences, 124-24.

Robertson, A.H.F., 2011. Late Palaeozoic - Cenozoic tectonic development of Greece and Albania in the context of alternative reconstructions of Tethys in the Eastern Mediterranean region. International Geology Review, 54(4), 373-454.

Roure, F., Andriessen, P., Callot, J.P., Ferket, H., Gonzales, E., Guilhaumou, N., Hardebol, N., Lacombe, O., Malandain, J., Mougin, P., Muska, K., Ortuño, S., Sassi, W., Swennen, R. \& Vilasi, N., 2010a. The use of paleo-thermo-barometers and coupled thermal, fluid flow and pore fluid pressure modelling for hydrocarbon and reservoir prediction in fold and thrust belts. In Goffey G.P., Craig J., Needham T. and Scott R., eds., Hydrocarbons in contractional belts, Geological Society, London, Spec. Pub., 348, 87-114.

Roure, F., Cloetingh S., Scheck-Wenderoth M. and Ziegler P., 2010b. Achievements and challenges in sedimentary basin analysis: a review. In: S. Cloetingh \& G. Negendank. New Frontiers in integrated Solid Earth Sciences. International year of Planet Earth, Springer. doi: 10.1007/978-90-481-2737-5-5.

Roure F., Nazaj S., Mushka K., Fili I., Cadet J.P. and Bonneau M., 2004. Kinematic evolution and petroleum systems: an appraisal of the Outer Albanides. In McClay, ed., Thrust Tectonics and Hydrocarbon Systems, AAPG Mem. 82, Ch. 24, 474-493.

Roure F., Sadiku U. and Valbona U., 1995. Petroleum geology of the Albanian foothills. AAPG Nice, Guide-Book, 100 p.

Roure F., Swennen R., Schneider F., Faure J.L., Ferket H., Guilhaumou N., Osadetz K., Robion Ph. and Vendeginste V., 2005. Incidence and importance of tectonics and natural fluid migration on reservoir evolution in foreland fold-and-thrust belts. In Brosse E. et al., eds., Oil and Gas Science and Technology, Oil and Gas Science and Technology, Revue de l'IFP, 60, 67-106.

Saccani, E., Beccaluva, L., Photiades, A. and Zeda, O., 2011. Petrogenesis and tectonomagmatic significance of basalts and mantle peridotites from the Albanian-Greek ophiolites and sub-ophiolitic mélanges. New constraints for the Triassic-Jurassic evolution of the Neo-Tethys in the Dinaride sector. Lithos, 124(3-4), 227-242.

Schefer, S., Cvetković, V., Fügenschuh, B., Kounov, A., Ovtcharova, M., Schaltegger, U. and Schmid, S., 2011. Cenozoic granitoids in the Dinarides of southern Serbia: age of intrusion, isotope geochemistry, exhumation history and significance for the geodynamic evolution of the Balkan Peninsula. International Journal of Earth Sciences, $100(5), 1181-1206$.

Schlagintweit, F., Gawlick, H.-J., Missoni, S., Hoxha, L., Lein, R. and Frisch, W., 2008. The eroded Late Jurassic Kurbnesh carbonate platform in the Mirdita Ophiolite Zone of Albania and its bearing on the Jurassic orogeny of the Neotethys realm. Swiss Journal of Geosciences, 101(1), 125-138-138.

Schmid, S., Bernoulli, D., Fügenschuh, B., Matenco, L., Schefer, S., Schuster, R., Tischler, M. and Ustaszewski, K., 2008. The Alpine-Carpathian-Dinaridic orogenic system: 
correlation and evolution of tectonic units. Swiss Journal of Geosciences, 101(1), 139183.

Silo V., Muska K. and Silo E., 2013. Hydrocarbon evaluation aspects in Neogene clastic reservoirs, Vlora-Elbasan region, Albania. Italian Journal of geosciences, 132, this issue.

Speranza F., Islami L., Kissel C. and Hyseni A., 1995. Paleomagnetic evidence for Cenozoic clockwise rotation of the esternal Albanides. Earth and Planet. Sci. Letters, 129, 121134.

Speranza F., Kissel C., Islami L., Hyseni A. and Laj C., 1992. First paleomagnetic evidence for rotation of the Ionian zone in Albania. Geophysical Research Letters, 19, 7, 697-700.

Sulstarova E, Kociaj S, Muco B, Peci V., 2003. The Albanian earthquakes catalogue for historical and instrumental data with magnitude $M$ 4.5. Internal Report (behalf on NATO Project "Seismotectonic and Seismic Hazard Assessment in Albania", 19992002). Seismological Institute, Tirana, Albania.

Swennen R., Muska K. and Roure F., 2000. Fluid circulation in the Ionian fold and thrust belt (Albania): Implications for hydrocarbon prospectivity. Journal of Geochemical Exploration, 69, 629-634.

Van Geet M., Swennen R., Durmishi C., Roure F. and Muchez Ph., 2002. Paragenesis of Cretaceous to Eocene carbonate reservoirs in the Ionian foreland fold-and-thrust belt (Albania): Relation between tectonism and fluid flow. Sedimentology, 49, 697-718.

Vilasi N., 2009. Study of reservoir analogues in foreland fold-end-thrust belts. Sedimentology, diagenesis, deformation and fracturing of Upper Cretaceous-Eocene carbonate systems of the Ionian zone (Southern Albania). PhD Thesis, KU-Leuven, Belgium, $218 \mathrm{pp}$.

Vilasi N., Malandain J., Barrier L., Callot JP, Guilhaumou N., Lacombe O., Muska K., Roure F. and Swennen R, 2009. From outcrop and petrographic studies to basin-scale fluid flow modelling: the use of the Albanian natural laboratory for carbonate reservoir characterization. Tectonophysics, 474, 367-392

Vilasi N., Swennen R., and Roure F., 2006. Diagenesis and fracturing of Paleocene-Eocene carbonate turbidite systems in the Ionian Basin: The example of the Kelcyra area (Albania). Journal of Geochemical Exploration, 89, 409-413.

Vishnevskaya, V.S., Djeric, N. and Zakariadze, G.S., 2009. New data on Mesozoic Radiolaria of Serbia and Bosnia, and implications for the age and evolution of oceanic volcanic rocks in the Central and Northern Balkans. Lithos, 108(1-4), 72-105.

Vlahovic, I., Tisljar, J., Velic, I. and Maticec, D., 2005. Evolution of the Adriatic Carbonate Platform: Palaeogeography, main events and depositional dynamics. Palaeogeography, Palaeoclimatology, Palaeoecology, 220(3-4), 333-360.

Wagner, B., Wilke, T., Krastel-Gudegast, S., Grazhdani, A., Reicherter, K., Trajanovski, S., Zanchetta, G., 2009. Scientific collaboration on past speciation conditions in Lake Ohrid-SCOPSCO Workshop Report, Scientific Drilling, 7, 51-53.

Zappaterra E., 1994. Source rock distribution model of the Periadriatic region. AAPG Bulletin, 78, 3, 333-354.

\section{8- Figures caption}

Figure 1: Group picture of the participants to the post-conference field trip in the Ionian Basin from Vlora to Saranda and back to Tirana via Girokastra.

Figure 2: Schematic map of the Adratic Offshore and Albanides..

Figure 3: Regional cross-section in the Outer Albanides, outlining the basal intra-Triassic decollement level, as well as the results of an integrated petroleum modelling with Ceres (modified after Vilasi et al., 2009).

Figure 4: Bouguer anomaly map of Albania (after Alba-Seis, Kiratzi and Muco). 


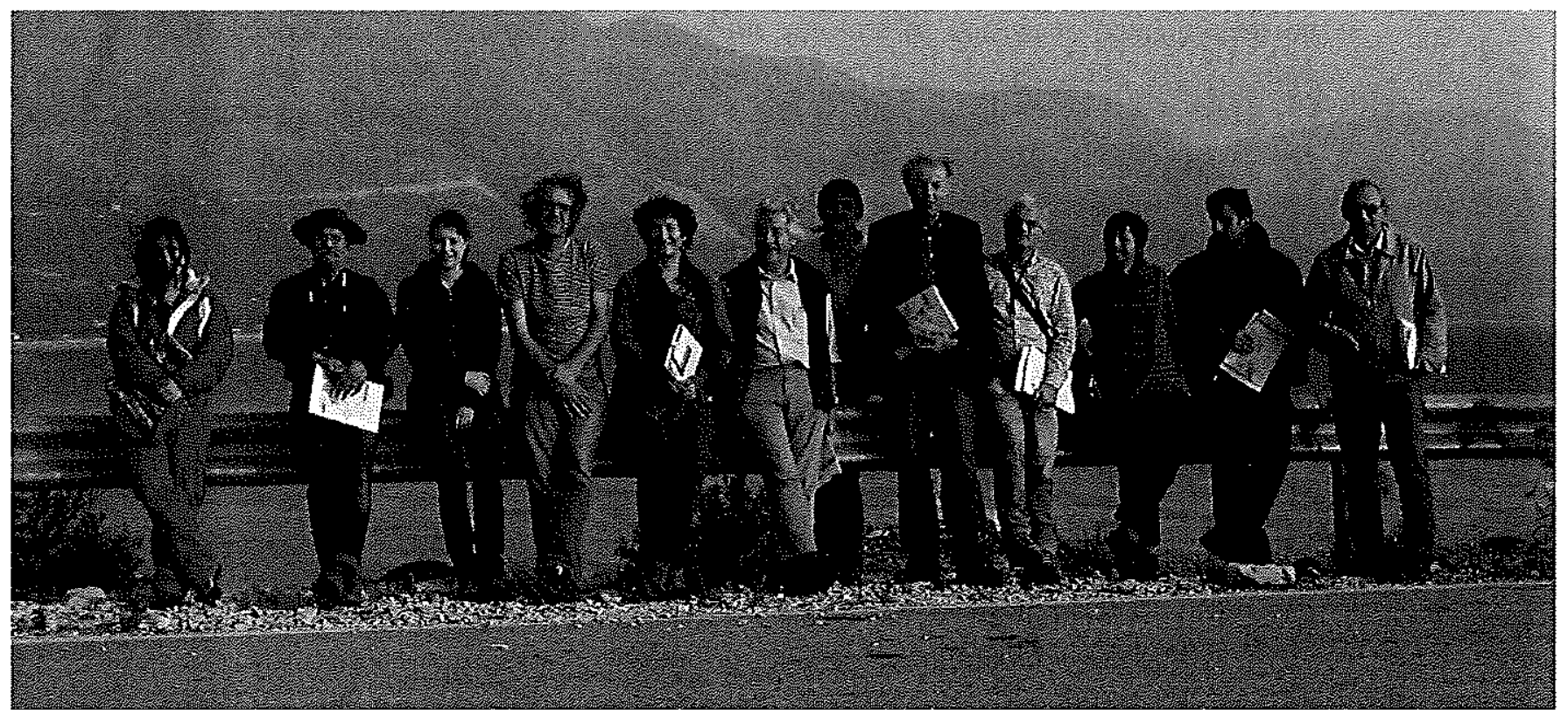

Figure 1: Group picture of the participants to the post-conference field trip in the Ionian Basin from Vlora to Saranda and back to Tirana via Girokastra. 


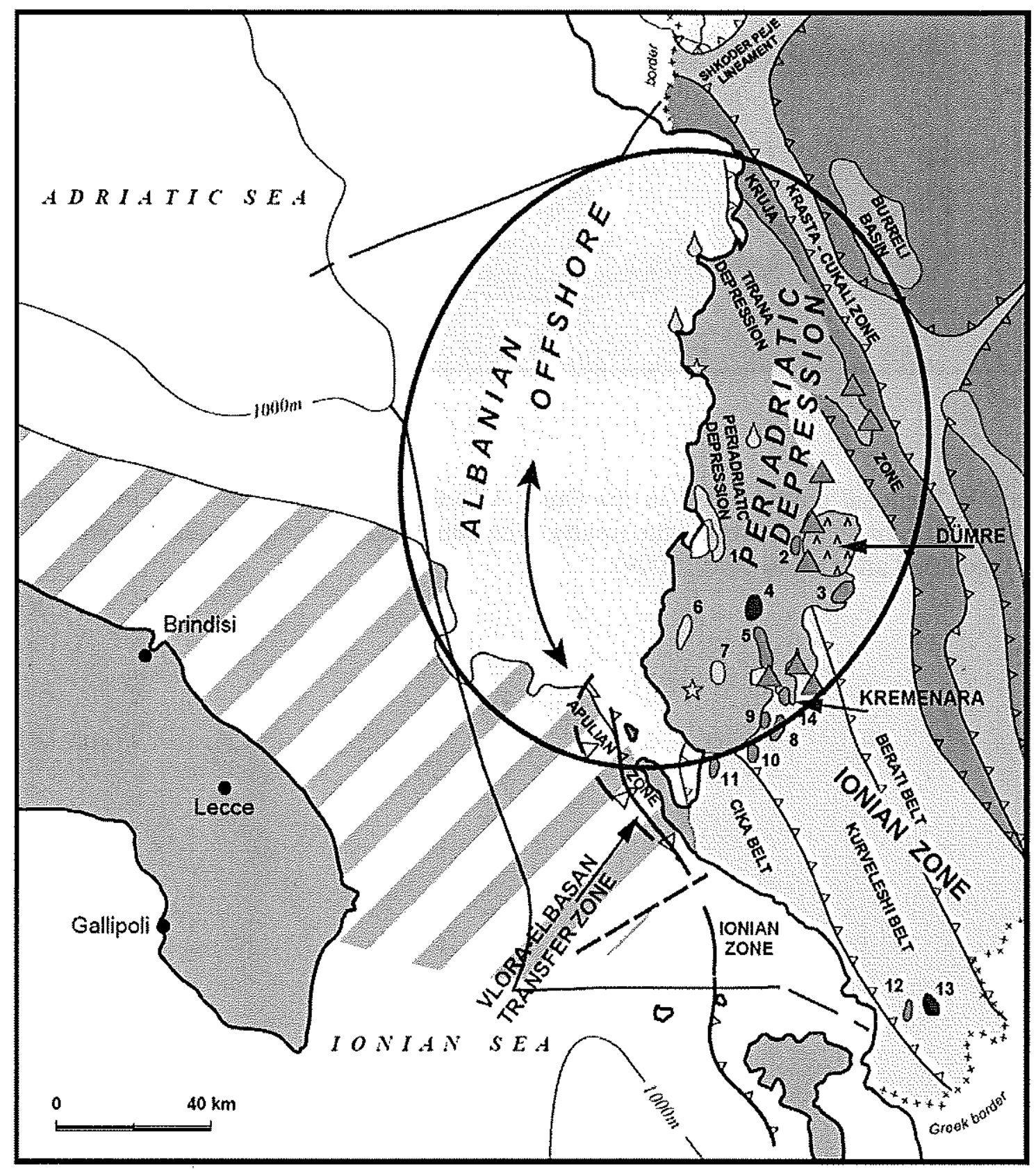

Figure 2: Schematic map of the Adratic Offshore and Albanides.. 


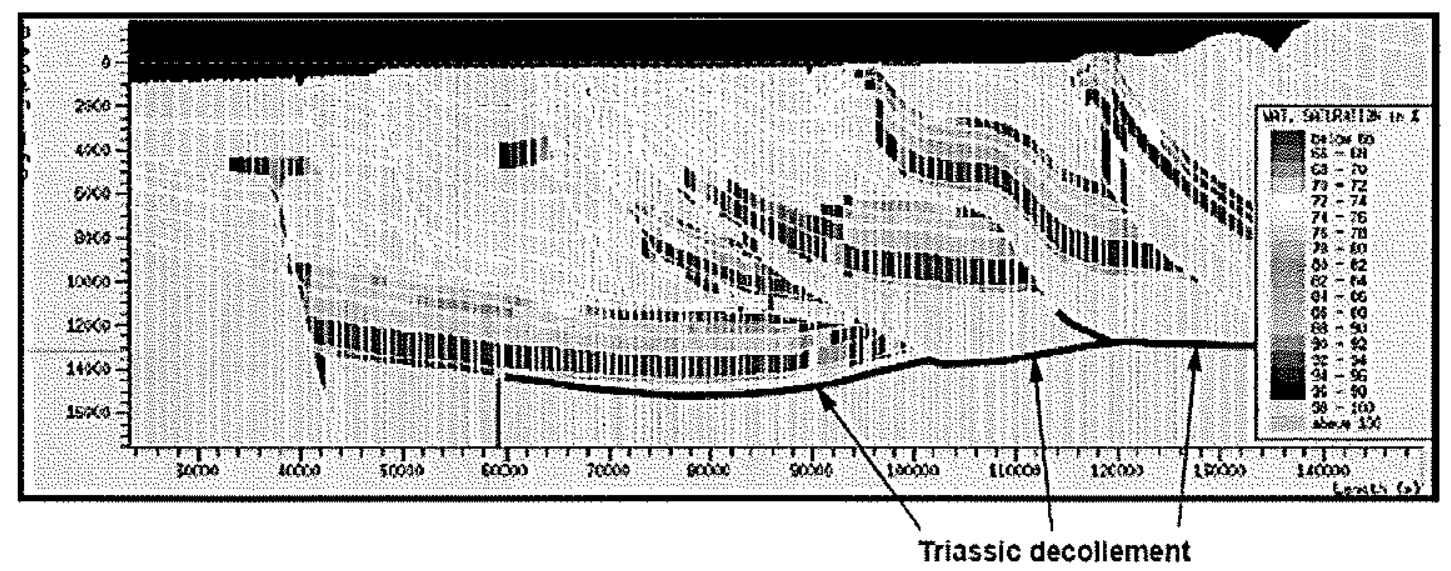

Figure 3: Regional cross-section in the Outer Albanides, outlining the basal intra-Triassic decollement level, as well as the results of an integrated petroleum modelling with Ceres (modified after Vilasi et al., 2009). 


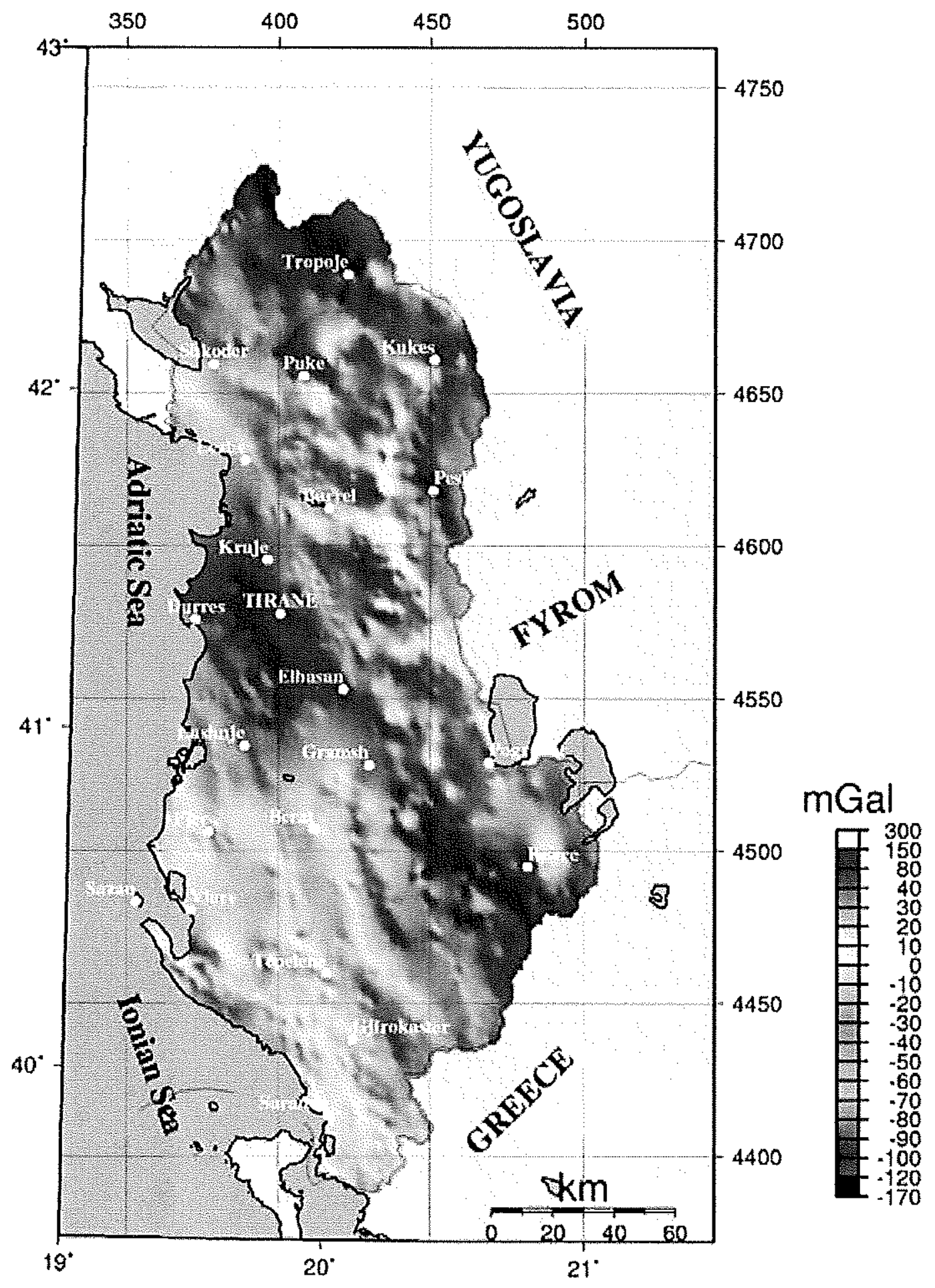

Figure 4: Bouguer anomaly map of Albania (after Alba-Seis, Kiratzi and Muco). 
